\title{
KAJIAN SOSIAL EKONOMI MASYARAKAT PESISIR DI KELURAHAN HAJORAN INDUK KABUPATEN TAPANULI TENGAH PROVINSI SUMATERA UTARA
}

\author{
SOCIO ECONOMIC STUDY OF COASTAL COMMUNITIES IN HAJORAN INDUK \\ VILLAGE, CENTRAL OF TAPANULI REGENCY, NORTH SUMATERA PROVINCE
}

\author{
Siti Rahmadani*, Juliana Pebrina Siburian \\ Sekolah Tinggi Perikanan dan Kelautan MATAULI, Pandan-Tapanuli Tengah, Sumatera Utara 22611 \\ Teregistrasi I tanggal: 01 April 2020; Diterima setelah perbaikan tanggal: 28 April 2020; Disetujui terbit \\ tanggal: 05 Mei 2020
}

\begin{abstract}
ABSTRAK
Penelitian ini bertujuan untuk mengetahui kondisi sosial ekonomi masyarakat pesisir di Kelurahan Hajoran Induk Kabupaten Tapanuli Tengah Provinsi Sumatera Utara. Penelitian ini merupakan penelitian deskriptif berdasarkan metode survei. Sampel diambil dengan metode proporsional area random sampling. Data dianalisis secara kualitatif dan kuantitatif. Hasil penelitian menunjukkan bahwa tingkat pendidikan nelayan tergolong rendah yaitu tamat $\mathrm{SD} /$ sederajat, status kepemilikan rumah sendiri dengan jenis papan dengan jumlah anggota keluarga 4 - 6 orang. Tingkat kesejahteraan keluarga yang rendah disebabkan oleh tingkat pendapatan yang rendah dari anggota keluarga. Dengan demikian masyarakat pesisir di Kelurahan Hajoran Induk tergolong miskin dengan tingkat pendapatan yang tergolong rendah.
\end{abstract}

Kata Kunci: Hajoran induk, kajian sosial ekonomi, masyarakat pesisir

\begin{abstract}
This study aimed to determine the state of socio-economic conditions of coastal communities in Hajoran Induk village, central of Tapanuli regency, North Sumatera province. This research is a descriptive study based on survey methods. Samples were taken by a proportional area random sampling method. Data were analyzed qualitatively and quantitatively. The results showed that the level of education of fishers was low, namely graduating from elementary school/ equivalent, the status of homeownership by board type with the number of family members of 4-6 people. The low-income level of family members causes a low level of family welfare. Thus the coastal community in the Hajoran Induk Village is classified as weak with a relatively low-income level.
\end{abstract}

Keywords: Hajoran Induk, socio-economic study, coastal communities

\section{PENDAHULUAN}

Kabupaten Tapanuli Tengah merupakan salah satu kabupaten bagian dari wilayah Provinsi Sumatera Utara

Korespondensi penulis:

*Email: rahmadani588@gmail.com

DOI: http://dx.doi.org/10.15578/plgc.v1i2.8871 yang terletak di bagian pesisir pantai barat Pulau Sumatera dengan panjang garis pantai sepanjang $200 \mathrm{~km}$. Wilayah Kabupaten Tapanuli Tengah terdiri atas 
darat dan laut memiliki luas $2.194,98 \mathrm{~km}^{2}$ darat dan $4.000 \mathrm{~km}^{2}$ laut (Badan Pusat Statistik Kabupaten Tapanuli Tengah, 2017). Potensi laut yang begitu besar menjadikan wilayah Tapanuli Tengah kaya akan sumber daya perikanan. Sehingga potensi ini menjadi ujung tombak bagi perekonomian masyarakat setempat.

Wilayah Kabupaten Tapanuli Tengah sebagian besar merupakan kawasan pesisir pantai dan memiliki potensi yang besar dalam sektor perikanan, khususnya perikanan laut. Sebagian besar masyarakat di pinggiran laut pada umumnya adalah nelayan yang pendapatan utamanya dari penjualan hasil tangkapan ikan. Demikian juga halnya di Kelurahan Hajoran Induk, sebagian besar masyarakat nelayan disana menjadi pengrajin ikan asin. Pemerintah dalam upaya untuk meningkatkan kesejahteraan nelayan telah menyusun programprogram yang telah dikembangkan, namun faktanya di lapangan, kehidupan para nelayan masih belum memadai. Umumnya kebanyakan nelayan di Indonesia dan di Kelurahan Hajoran khususnya, masih belum tergolong kepada kelas yang menengah atau mampu (Simanjuntak \& Pinem, 2013).

Kondisi ini tentu tidak terlepas dari keadaan geografis yang terletak di daerah pantai. Jumlah penduduk di kelurahan ini sebanyak 1820 jiwa dan 528 jiwa dari jumlah tersebut bermata pencaharian sebagai nelayan. Menyangkut aspek tersebut kegiatan ini dilakukan oleh keluarga yang bertujuan untuk meningkatkan kondisi sosial ekonomi dengan melibatkan anggota keluarga. Saat ini wilayah pesisir Hajoran Induk merupakan salah satu sasaran wilayah yang akan dikembangkan oleh pemerintah daerah melalui kantor BAPPEDA Kabupaten Tapanuli Tengah sebagai pusat pengembangan ekowisata bahari, dengan lebih khusus komponen oleh-oleh Kabupaten Tapanuli Tengah. Namun dari segi strategi pengembangan dalam konsep ekowisata bahari, masih belum terencana secara sistematis.

Data dasar tentang sosio-ekonomi yang menjadi acuan awal program belum ada. Berdasarkan kondisi tersebutlah maka diperlukan kajian tentang sosial dan ekonomi masyarakat pesisir di Kelurahan Hajoran Induk. Sehingga tujuan penelitian ini adalah untuk mengetahui kondisi sosial dan ekonomi masyarakat pesisir di Kelurahan Hajoran Induk.

\section{BAHAN DAN METODE}

Penelitian ini dilaksanakan pada akhir bulan November hingga bulan Desember 2018 di Kelurahan Hajoran Induk Kecamatan Pandan Kabupaten Tapanuli Tengah Provinsi Sumatera Utara. Pengumpulan data primer dilakukan dari wawancara langsung dengan masyarakat pesisir di Kelurahan Hajoran Induk. Sedangkan data sekunder diperoleh dari kantor dinas terkait. Adapun jumlah sampel dalam penelitian ini adalah 84 responden.

Analisis data dilakukan dengan cara menghitung beberapa parameter analisis deskriptif, dan analisis pendapatan. Untuk aspek sosial digunakan metode analisis deskriptif. Metode dalam meneliti status manusia, suatu objek, suatu kondisi, suatu sistem pemikiran ataupun suatu kelas peristiwa pada masa yang akan datang disebut metode deskriptif. Menurut Usman \& Abdi (2012), metode deskriptif bertujuan untuk menggambarkan secara tepat sifat-sifat individu, keadaan, gejala, atau hal-hal yang khusus dalam masyarakat. Penelitian jenis ini bisa sudah ada hipotesis, namun dapat pula belum ada hipotesis, tergantung dari ada tidaknya pengetahuan tentang masalah yang diteliti.

Pendapatan adalah selisih antara penerimaan dengan semua biaya yang dikeluarkan selama melakukan kegiatan usaha. Pendapatan meliputi pendapatan kotor (penerimaan total) dan pendapatan bersih. Pendapatan kotor adalah nilai 
produksi komoditas pertanian secara keseluruhan sebelum dikurangi biaya produksi Rahim dan Hastuti (2007). Untuk aspek ekonomi digunakan analisis pendapatan untuk menghitung pendapatan responden. Rumus yang digunakan sebagaimana Pers. 1 (Soekartawi, 1998).

$$
\Pi=\mathrm{TR}-\mathrm{TC}
$$

Keterangan:

$\Pi=$ Pendapatan $(\mathrm{Rp})$
$\mathrm{TR}=$ total Revenue/ Pendapatan (Rp/bulan) $\mathrm{TC}=$ Total cost/biaya $(\mathrm{Rp} / \mathrm{bulan})$

\section{HASIL DAN BAHASAN \\ HASIL \\ Kondisi Demografis}

Jumlah penduduk pada tahun 2018 di Kelurahan Hajoran Induk adalah 2.625 jiwa, yang terdiri dari 4 lingkungan (dusun). Secara rinci jumlah penduduk di Kelurahan Hajoran Induk tahun 2018 dapat dilihat pada Tabel 1.

Tabel 1. Jumlah Penduduk Kelurahan Hajoran Induk Tahun 2018.

Table 1. Total population in Hajoran Induk Village 2018

\begin{tabular}{clrrrr}
\hline No & Kelurahan Hajoran & Jumlah KK & Laki-laki & Perempuan & $\begin{array}{c}\text { Jumlah } \\
\text { Penduduk }\end{array}$ \\
\hline 1 & Lingkungan I & 136 & 319 & 313 & 632 \\
2 & Lingkungan II & 198 & 594 & 496 & 1090 \\
3 & Lingkungan III & 127 & 263 & 278 & 541 \\
4 & Lingkungan IV & 82 & 190 & 172 & 362 \\
\hline \multicolumn{2}{l}{ Total } & 540 & 1366 & 1259 & 2625 \\
\hline
\end{tabular}

Sumber: Kantor Kelurahan Hajoran Induk (2018)

\section{Karakteristik Sosial Masyarakat}

Karakteristik responden masyarakat pesisir yang dimaksud dalam penelitian ini meliputi karakteristik sosial yang terdiri dari usia, tingkat pendidikan, kondisi rumah nelayan, dan jumlah anggota rumah tangga nelayan. Nelayan yang dijadikan sebagai responden dalam penelitian ini berusia antara 34 - 68 tahun dengan rincian seperti pada Tabel 2.

Tabel 2. Karakteristik Nelayan Berdasarkan Kelompok Umur

Table 2. Fishermen characteristics based on age group

\begin{tabular}{|c|c|c|c|}
\hline \multirow{2}{*}{ No } & \multirow{2}{*}{ Umur Responden (tahun) } & \multicolumn{2}{|c|}{ Nelayan } \\
\cline { 2 - 4 } & & Jumlah (jiwa) & Persentase (\%) \\
\hline 1 & $15-45$ & 59 & 70,24 \\
\hline 2 & $46-65$ & 19 & 22,62 \\
\hline 3 & $<15$ dan $>65$ & 6 & 7,14 \\
\hline \multicolumn{2}{|c|}{ Total } & 84 & 100 \\
\hline
\end{tabular}

Tingkat pendidikan masyarakat pesisir di Kelurahan Hajoran Induk dapat dilihat pada Gambar 1. Tingkat pendidikan nelayan di Kelurahan Hajoran Induk tergolong rendah, hal ini terlihat dari pendidikan yang mereka peroleh. Sebagian besar nelayan hanya menamatkan pendidikannya di jenjang SD saja.

Status kepemilikan rumah bagi setiap orang dapat menunjukkan status sosial dalam masyarakat. Berikut dapat dilihat status kepemilikan rumah nelayan di Kelurahan Hajoran Induk pada Gambar 2. Tempat tinggal rumah tangga nelayan 
di Kelurahan Hajoran Induk sebagian

jenis/sifat rumah yang ditempati nelayan besar terbuat dari papan. Berikut rincian dapat dilihat pada Gambar 3.

\section{Tingkat Pendidikan Nelayan di Kelurahan Hajoran Induk}

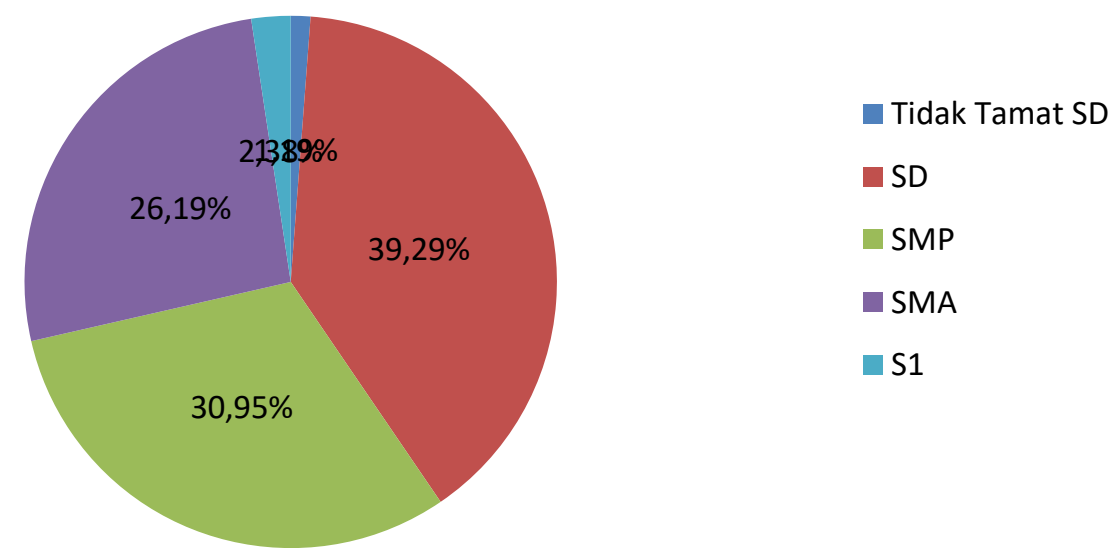

Gambar 1. Tingkat Pendidikan Nelayan di Kelurahan Hajoran Induk Figure 1. Education level of fishermen in Hajoran Induk Village

\section{Status Kepemilikan Rumah Nelayan di Kelurahan Hajoran Induk}

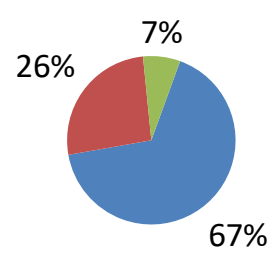

$$
\begin{aligned}
& \text { Milik sendiri } \\
& \text { Sewa } \\
& \text { Tinggal dengan orang } \\
& \text { tua }
\end{aligned}
$$

Gambar 2. Status Kepemilikan Rumah Nelayan di Kelurahan Hajoran Induk

Figure 2. The ownership status of the fishermen in Hajoran Induk Village

\section{Jenis/Sifat Rumah yang Ditempati Nelayan di Kelurahan Hajoran Induk}

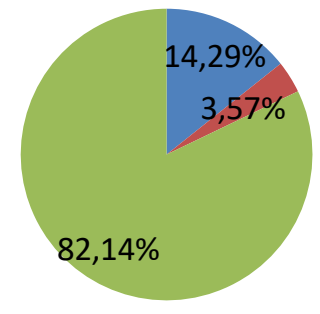

$$
\begin{aligned}
& \text { Permanen } \\
& \text { Semi Permanen } \\
& \text { Papan }
\end{aligned}
$$

Gambar 3. Jenis/Sifat Rumah yang Ditempati Nelayan di Kelurahan Hajoran Induk Figure 3. Type /nature of the house occupied by fishermen in Hajoran Induk Village 
Jumlah anggota keluarga nelayan yang dominan dalam penelitian ini, berkisar antara 4 orang sampai dengan 6 orang. Berikut dapat dilihat rincian jumlah anggota keluarga nelayan di Kelurahan Hajoran Induk pada Tabel 3.
Berdasarkan hasil analisis data diketahui bahwa status nelayan yang kawin berjumlah 74 orang. Berikut dapat kita lihat status nelayan di Kelurahan Hajoran Induk pada Gambar 4.

Tabel 3. Jumlah Anggota Keluarga Nelayan di Kelurahan Hajoran Induk Table 3. Total of family members of fishermen in Hajoran Induk Village

\begin{tabular}{|c|c|c|c|}
\hline \multirow{2}{*}{ No } & \multirow{2}{*}{$\begin{array}{c}\text { Jumlah Anggota } \\
\text { Keluarga }\end{array}$} & \multicolumn{2}{|c|}{ Nelayan } \\
\cline { 3 - 4 } & 1. & Jumlah (KK) & Persentase (\%) \\
\hline 2. & $1-3$ & 28 & 33.33 \\
\hline 3. & $>6$ & 48 & 57.14 \\
\hline \multicolumn{2}{|c|}{ Total } & 8 & 9.53 \\
\hline
\end{tabular}

\section{Status Nelayan di Kelurahan Hajoran Induk}

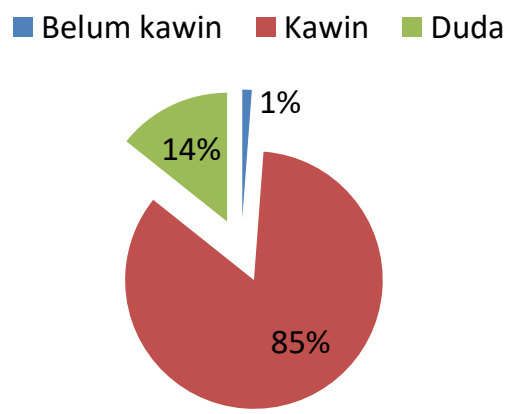

Gambar 4. Status Nelayan di Kelurahan Hajoran Induk Figure 4. Fishermen status in Hajoran Induk Village

\section{Karakteristik Ekonomi Nelayan}

Analisis aspek ekonomi masyarakat nelayan di Kelurahan Hajoran Induk dapat dirumuskan dengan menggambarkan mata pencaharian mayoritas penduduk dan tingkat pendapatan penduduk per bulan. Tingkat pendapatan nelayan di Kelurahan Hajoran Induk sangat bervariasi berkisar antara Rp 1.000.000 sampai dengan > Rp 5.000.000. Rincian tingkat pendapatan nelayan di Kelurahan Hajoran Induk dapat kita lihat pada Tabel 4.

Hasil penelitian menunjukan bahwa masyarakat nelayan sangat bervariasi dalam membelanjakan pendapatannya. Rincian biaya kebutuhan hidup nelayan di Kelurahan Hajoran Induk dapat dilihat pada Tabel 5.

Tabel 4. Pendapatan Kotor Masyarakat Nelayan di Kelurahan Hajoran Induk

Table 4. Gross income of the fishing community in Hajoran Induk Village

\begin{tabular}{cccc}
\hline No & \multicolumn{1}{c}{ Pendapatan Kotor } & Frekuensi & Persentase (\%) \\
\hline 1 & Rp 1.000.000-Rp 1.900.000 & 20 & 23,81 \\
2 & Rp 2.000.000-Rp 2.900.000 & 28 & 33,33 \\
3 & Rp 3.000.000-Rp 5.000.000 & 29 & 34,52 \\
4 & $>$ Rp 5.000.000 & 7 & 8,34 \\
\hline
\end{tabular}


Kajian Sosial Ekonomi Masyarakat..... Sumatera Utara (Rahmadani, et al)

Tabel 5. Biaya Kebutuhan Hidup Masyarakat Nelayan di Kelurahan Hajoran Induk

Table 5. Living expenses of the fishing community in Hajoran Induk Village

\begin{tabular}{cccc}
\hline No & Biaya Kebutuhan Hidup & Frekuensi & Persentase (\%) \\
\hline 1 & $\mathrm{Rp} 1.000 .000-\operatorname{Rp~} 1.800 .000$ & 42 & 50 \\
2 & $\mathrm{Rp} 1.900 .000-\operatorname{Rp~} 2.800 .000$ & 26 & 30,95 \\
3 & $\mathrm{Rp} 2.900 .000-\operatorname{Rp~} 3.900 .000$ & 10 & 11,91 \\
4 & $>$ Rp 4.000.000 & 6 & 7,11 \\
\hline \multicolumn{2}{l}{ Jumlah } & 84 & 100 \\
\hline
\end{tabular}

Pendapatan bersih adalah selisih pendapatan kotor dengan total pengeluaran. Adapun pendapatan bersih nelayan di Kelurahan Hajoran Induk berkisar $<\mathrm{Rp} 100.000$ sampai dengan $>\operatorname{Rp}$ 1.000.000. Rincian pendapatan bersih nelayan dapat dilihat pada Tabel 6 .

Tabel 6. Pendapatan Bersih Masyarakat Nelayan di Kelurahan Hajoran Induk Table 6. Net income of the fishing community in Hajoran Induk Village

\begin{tabular}{|c|c|c|c|}
\hline No & Pendapatan Bersih & Frekuensi & Persentase (\%) \\
\hline 1 & $<\mathrm{Rp} 100.000-\mathrm{Rp} 110.000$ & 7 & 8,33 \\
\hline 2 & $\operatorname{Rp} 500.000$ & 38 & 45,24 \\
\hline 3 & $>\operatorname{Rp} 500.000-\operatorname{Rp} 1.000 .000$ & 16 & 19,05 \\
\hline \multirow[t]{2}{*}{4} & $>\mathrm{Rp} 1.000 .000$ & 23 & 27,38 \\
\hline & Jumlah & 84 & 100 \\
\hline
\end{tabular}

\section{BAHASAN}

Kelurahan Hajoran Induk merupakan salah satu kelurahan yang terkenal di Kabupaten Tapanuli Tengah dengan pengolahan ikan hasil tangkapan yang cukup banyak dalam bentuk ikan asin dan ikan rebus. Kelurahan Hajoran pada mulanya tidak begitu terkenal di Tapanuli Tengah karena belum terdapat kehidupan dan masyarakat yang bertempat tinggal di kelurahan tersebut masih sedikit. Namun, memasuki tahun 1971, sejak kedatangan Etnis Bugis perlahan-lahan Kelurahan Hajoran sudah mulai memiliki kehidupan.

Pada tahun 1983 masyarakat nelayan Kelurahan Hajoran mulai mengolah hasil tangkapan nelayan dan mengirim hasil olahan ikan berupa ikan asin ke luar desa maupun kota. Dari hasil tangkapan masyarakat nelayan inilah yang membuat perekonomian mereka semakin meningkat. Dengan mulai dibuatnya bagan pancang, para masyarakat nelayan mulai menangkap ikan dengan menggunakan cara kerja berkelompok ataupun sendiri. Selain bagan pancang, bagan bot juga digunakan para masyarakat pendatang.

Kelurahan Hajoran Induk terdiri dari 4 lingkungan (dusun). Lingkungan yang memiliki jumlah penduduk paling banyak adalah Lingkungan II, dengan total 1.090 jiwa yang terdiri dari 198 kepala keluarga. Sedangkan lingkungan yang mempunyai jumlah penduduk paling sedikit adalah Lingkungan IV yang terdiri dari 82 kepala keluarga.

Kelompok umur nelayan di Kelurahan Hajoran Induk paling banyak adalah 15 - 45 tahun dengan total 59 jiwa. Sedangkan kelompok umur nelayan yang paling sedikit adalah $<15$ tahun dan $>65$ tahun dengan jumlah 6 jiwa. Kelompok umur ini termasuk pada usia kurang produktif. Pada golongan umur $15-45$ tahun, nelayan berada pada kondisi fisik yang prima dan kemampuan berfikir yang lebih matang. Tenaga fisik yang kuat sangat dibutuhkan nelayan untuk melakukan kegiatan operasional 
penangkapan ikan yang berat, misalnya menurunkan dan mengangkat alat tangkap, serta mendorong, menarik dan/atau menambatkan perahu.

Hal ini menjelaskan bahwa nelayan di Kelurahan Hajoran Induk masuk kedalam kelompok usia produktif. Hasil penelitian ini didukung oleh Putri \& Setiawina (2013), mengatakan bahwa usia produktif berkisar antara $15-64$ tahun. Di masa tersebut secara umum semakin bertambahnya usia maka pendapatan akan semakin meningkat sesuai dengan jenis pekerjaan yang dilakukan. Namun ketika seseorang telah melewati masa produktif maka semakin menurun kekuatan fisiknya sehingga produktivitas akan menurun yang berakibat pada pendapatan yang diterima. Sebagaimana Salladien (2003), usia dikelompokkan dalam tiga kelompok usia kerja yaitu usia sangat produktif (15 - 45 tahun), usia produktif (46 - 65 tahun) dan usia kurang produktif $(<15$ tahun dan $>$ 65 tahun).

Berdasarkan hasil wawancara terhadap nelayan, tingkat pendidikan nelayan yang rendah di Kelurahan Hajoran Induk disebabkan oleh beberapa hal, antara lain: besarnya biaya pendidikan, tidak ada keinginan untuk berubah dan fasilitas pendidikan yang terbatas. Besarnya biaya yang dikeluarkan untuk memperoleh pendidikan bila dibandingkan antara pendapatan yang diperoleh nelayan sehari-sehari menyebabkan mereka enggan bersekolah. Masyarakat merasa bahwa nelayan merupakan pekerjaan turun-temurun dan keahlian melaut merupakan warisan nenek moyang. Sehingga mereka enggan untuk beralih mata pencahariannya. Fasilitas pendidikan yang terdapat di Kelurahan Hajoran Induk adalah 1 SD dan 1 SLTP. Kondisi ini menyebabkan kesempatan masyarakat untuk memperoleh pendidikan semakin kecil karena terbatasnya fasilitas pendidikan yang ada dan tingginya biaya pendidikan. Selain itu, kondisi ini menimbulkan kesulitan bagi masyarakat nelayan untuk melanjutkan pendidikan ke jenjang yang lebih tinggi.

Pendidikan merupakan investasi jangka panjang untuk mengubah kualitas masa depan. Semakin tinggi tingkat pendidikan akan mempengaruhi perolehan pendapatan seseorang. Seperti halnya yang diungkapkan oleh Suhardan et al (2012), bahwa pendidikan memberi keuntungan ganda, yaitu meningkatkan nilai harga diri dan kemampuan produktivitas yang besar. Dengan adanya pendidikan dapat memproses manusia hingga menjadi manusia produktif yang memiliki kemampuan membangun, serta pembangunan itu sendiri dilakukan oleh manusia yang dibangun oleh pendidikan. Selain itu pengaruh jangka panjang pendidikan dari sisi fisik dapat memberikan uang yang cukup luas dalam membina kesehatan dan pertumbuhan fisik. Sebagaimana Vebriyanti (2014), mengatakan hasil empirik menunjukkan bahwa kondisi pendidikan nelayan yang rendah menyebabkan nelayan memiliki hambatan dalam mengakses berbagai program yang ada.

Hasil penelitian menunjukkan bahwa $67 \%$ masyarakat nelayan di Kelurahan Hajoran Induk telah memiliki rumah sendiri. Status Kepemilikan rumah merupakan salah satu indikator yang digunakan untuk mengukur kesejahteraan keluarga (Statistic New Zaeland, 1998 in Milligan et.al, 2006). Hasil penelitian kuantitatif menunjukkan kepemilikan rumah berhubungan signifikan dengan kesejahteraan materi. Kepemilikan rumah merupakan indikator kekayaan dan status sosial, yang sangat berhubungan dengan pendapatan status sosial ekonomi seseorang.

Berdasarkan hasil observasi di lapangan serta analisis data diketahui bahwa $82,14 \%$ jenis rumah masyarakat nelayan di Kelurahan Hajoran Induk terbuat dari papan. Hal ini sesuai dengan kondisi tempat tinggal nelayan yang 
berada di pesisir. Rumah yang terbuat dari papan merupakan ciri khas dari perumahan nelayan.

Jumlah anggota keluarga nelayan yang dominan berdasarkan analisis data berkisar antara 4 - 6 orang. Artinya bahwa rata-rata jumlah tanggungan keluarga nelayan tergolong besar yang akan mempengaruhi pola konsumsinya. Sebagaimana Syafrini (2014), besarnya jumlah anggota keluarga akan berpengaruh secara tidak langsung pada pola konsumsi dan biaya hidup rumah tangga. Semakin banyak jumlah anggota keluarga maka akan semakin tinggi kebutuhan konsumsinya.

Berdasarkan hasil analisis data menunjukkan bahwa status perkawinan masyarakat nelayan di Kelurahan Hajoran Induk bervariasi, dengan status kawin, belum kawin, dan duda. Sebagian besar dari masyarakat nelayan tersebut berstatus kawin. Sebagaimana Adiotomo \& Samosir (2011), mengatakan status perkawinan merupakan suatu karakteristik demografi yang mencakup aspek sosial, ekonomi, biologis, hukum dan agama. Selain dapat mempengaruhi jumlah penduduk melalui kelahiran, perkawinan dapat mengubah komposisi penduduk. Perubahan itu merupakan status perkawinan itu sendiri.

Pendapatan kotor masyarakat nelayan di Kelurahan Hajoran Induk sangat bervariasi, berkisar antara Rp 1.000.000 - Rp 5.000.000. Perbedaan ini disebabkan oleh beberapa faktor, diantaranya status nelayan pemilik kapal dan nelayan buruh, kepemilikan bagan, kepemilikan usaha pengolahan ikan, dan usaha sampingan. Sebagaimana Pande \& Karmini (2014), menyampaikan bahwa pendapatan adalah jumlah penghasilan riil dari seluruh anggota rumah tangga yang disumbangkan untuk memenuhi kebutuhan bersama maupun perorangan. Berdasarkan hasil analisis data biaya kebutuhan hidup masyarakat nelayan di Kelurahan Hajoran Induk sangat bervariasi, yaitu berkisar antara
Rp 1.000.000 sampai dengan $>$ Rp 4.000.000. Proporsi terbesar biaya kebutuhan hidup sebagian besar masyarakat nelayan adalah untuk keperluan belanja atau konsumsi seharihari, sedangkan untuk kebutuhan ikannya dapat dipenuhinya sendiri. Berdasarkan penjelasan diatas dapat disimpulkan bahwa masyarakat nelayan Kelurahan Hajoran Induk mempunyai pendapatan yang bervariasi. Rahman \& Alhifni (2018), mengatakan terdapat perbedaan yang cukup jauh antara nelayan kecil dengan nelayan juragan, baik dari segi pendapatan maupun kebutuhan operasional dan kebutuhan sehari-hari. Meskipun pendapatan nelayan juragan berpendapatan jauh lebih besar, akan tetapi itu semua tetap bergantung kepada keuntungan nelayan juragan.

Sebagian besar masyarakat nelayan di Kelurahan Hajoran Induk memiliki pendapatan bersih yang tergolong kecil. Sehingga sebagian besar dari nelayan tersebut tidak mempunyai tabungan di bank. Sebagaimana Soekartawi (2012), menjelaskan bahwa pendapatan akan mempengaruhi banyaknya barang yang dikonsumsi. Sering kali dijumpai dengan bertambahnya pendapatan maka barang yang dikonsumsi bukan saja bertambah tetapi juga kualitas barang tersebut ikut menjadi perhatian.

\section{SIMPULAN}

Berdasarkan karakteristik sosial masyarakat nelayan di Kelurahan Hajoran Induk, diketahui bahwa tingkat pendidikan responden tergolong rendah yaitu pendidikan tamat SD/Sederajat sebesar 39,29\%; status kepemilikan rumah sendiri dengan jenis papan sebesar 67\%; jumlah anggota keluarga nelayan berkisar $4-6$ orang atau $57,14 \%$; serta status nelayan yang sudah menikah sebesar $85 \%$.

Karakteristik ekonomi dapat dilihat dari tingkat pendapatan. Adapun pendapatan masyarakat pesisir di 
Kelurahan Hajoran Induk dikategorikan rendah. Hal ini disebabkan karena sebagian besar nelayan tidak mempunyai alat tangkap sendiri sehingga hanya berstatus sebagai nelayan buruh.

\section{DAFTAR PUSTAKA}

Adiotomo, S.M., \& Samosir, O.B. (Eds). (2011). Dasar-Dasar Demografi. Jakarta: Salemba Empat.

Badan Pusat Statistik. (2017). Kabupaten Tapanuli Tengah Dalam Angka 2017. Pandan: BPS Kab. Tapanuli Tengah.

Miligan et.al. (2006). Family Wilbeing Indicators from the 1981-2001 New Zealand Censuses. Statistics New Zealand.

Pande, P.E.A., \& Karmini, N. L. (2014). Pengaruh Pendapatan, Jumlah Anggota Keluarga, dan Pendidikan Terhadap Pola Konsumsi Rumah Tangga Miskin di Kecamatan Gianyar. Jurnal Zoostek, 34 (1), 3948.

Putri, A.D., \& Setiawina, N.D. (2013). Pengaruh Umur, Pendidikan, Pekerjaan Terhadap Pendapatan Rumah Tangga Miskin di Desa Bebandem. E-Jurnal Ekonomi Pembangunan, 2 (4), 173-180.

Rahim. A., \& Hastuti. D.R.W. (2007). Ekonomi Pertanian. Jakarta: Penebar Swadaya.
Rahman, A. A., \& Alhifni, A. (2018). Analisis Kebutuhan Nelayan Terhadap Pembiayaan LKMS. Jurnal Syarikah, 4 (2), 152-162.

Salladien. (2003). Strategi Pembangunan Kependudukan dan Kebijakan yang Ditempuh di Era Global. Malang: Universitas Negeri Malang.

Simanjuntak, S., \& Pinem, K. (2013). Keadaan Sosial Ekonomi Pengrajin Ikan Asin di Desa Hajoran Kecamatan Pandan Kabupaten Tapanuli Tengah. Jurnal Geografi, 5 (1), 135-148.

Soekartawi. (2012) Faktor-faktor Produksi. Jakarta: Salemba Empat. (1998). Analisis Usaha Tani. Jakarta: Penerbit Universitas Indonesia.

Suhardan, D., Riduwan., \& Enas. (2012). Ekonomi dan Pembiayaan Pembangunan. Bandung: Alfabeta.

Syafrini, D. (2014). Nelayan Vs Rentenir Studi Ketergantungan Nelayan terhadap Rentenir pada Masyarakat Pesisir. Jurnal Ilmu Sosial Mamangan, 1 (2), 67-74.

Usman, R., \& Abdi (2012). Metode Penelitian Sosial dan Ekonomi Teori dan Aplikasi. Bandung: Alfabeta.

Vebriyanti, D. (2014). Kondisi Sosial Ekonomi Dan Pemberdayaan Nelayan Tangkap Kota Tegal, Jawa Tengah. Jurnal Kependudukan Indonesia, 9(1), 45-58. 